\title{
Vitreous Floater
}

National Cancer Institute

\section{Source}

National Cancer Institute. Vitreous Floater. NCI Thesaurus. Code C50808.

Spots before the eyes caused by opaque cell fragments in the vitreous humor or lens. 